DOI 10.14746/ssp.2020.2.2

Marcin PIECHOCKI

Uniwersytet im. Adama Mickiewicza w Poznaniu

ORCID: 0000-0001-9574-4755

Jacek WYSZYŃSKI

Uniwersytet im. Adama Mickiewicza w Poznaniu

ORCID: 0000-0002-2195-2233

\title{
Dobra zmiana? Niemcy na antenie Wiadomości TVP w 2015 i 2017 r.
}

Streszczenie: Artykuł jest rezultatem analizy zawartości głównych wydań Wiadomości TVP, które zostały wyemitowane pomiędzy 1.03 a 31.052015 i 2017 roku. Celem artykułu jest udzielenie odpowiedzi na pytanie, w jaki sposób ukazywane w nich są Niemcy i czy można mówić o zmianie w tym zakresie, która jest wynikiem wyborów w 2015 roku. Badanie pokazuje, że tematyka niemiecka nie ma neutralnego charakteru, a Niemcy są często instrumentalnie wykorzystywane jako negatywny punkt odniesienia.

Słowa kluczowe: TVP, analiza zawartości, Niemcy, telewizja

Tematyka niemiecka często nie ma neutralnego charakteru i bywa 1 instrumentalnie wykorzystywana $\mathrm{w}$ toczonych $\mathrm{w}$ kraju dyskusjach i sporach. Wystarczy wspomnieć sprawę zwrotu majątku Agnes Trawny w miejscowości Narty (na mocy Wyroku Sądu Najwyższego z 13.12.2005) oraz kampanię prezydencką w 2005 roku i informację o walkach Józefa Tuska, dziadka Donalda, w szeregach Wehrmachtu. Za taką sugestię Jacek Kurski stracił stanowisko szefa kampanii kandydata Prawa i Sprawiedliwości, Lecha Kaczyńskiego, który przeprosił za te insynuacje (ROB, 2005).

Analiza została przeprowadzona na prośbę naukowców z Uniwersytetu w Poczdamie, z którymi autorzy od lat współpracują w ramach polsko-niemiecko-rosyjskiej grupy badawczej. Rezultaty analogicznego monitoringu w odniesieniu do obrazu Federacji Rosyjskiej opublikowano w jednym z ukazujących się tam czasopism (Piechocki, Wyszyński, 2018).

U podstaw przeprowadzonych przez autorów badań legło przypuszczenie, iż tendencja do retorycznego wykorzystywania figury Niemiec 
znajduje mocniejszy wyraz w serwisach informacyjnych Telewizji Polskiej w 2017 roku, co wynika ze zmiany układu sił politycznych w kraju i nowego kierownictwa tejże. W styczniu 2016 roku prezesem TVP został Jacek Kurski, były polityk Prawa i Sprawiedliwości i jeden z twórców Solidarnej Polski ${ }^{1}$. Konstrukcja systemu medialnego sprawia, że nadawca publiczny zostaje po wyborach de facto podporządkowany rządzącej koalicji, choć zakres tych ingerencji może się różnić. W monografii poświęconej nadawcy publicznemu, Katarzyna Doktorowicz przypomina, iż już od początku przekształcania nadawcy państwowego w publicznego, próbowano nieformalnie podporządkować politykę informacyjną aktualnie rządzącym. Wskazuje ona również na niedostatki niezależności instytucjonalnej, które współwystępują z brakiem niezależności dziennikarskiej (Doktorowicz, 2010, s. 42). Pogłębieniu tej tendencji służyło powstanie w 2016 roku Rady Mediów Narodowych, która powołuje władze mediów publicznych. W jej skład wchodzi trzech członków wybieranych przez Sejm i dwóch przez Prezydenta, spośród wskazanych przez kluby opozycyjne (art. 3 i 6 ustawy o Radzie Mediów Narodowych).

Powyższe założenia przyjęte przez autorów zdają się znajdować potwierdzenie w badaniach Macieja Mrozowskiego i Tatiany Popadiak-Kuligowskiej (2016), choć rozważania wyżej wspomnianych prowadzone są wielokierunkowo i nie poświęcają dużej uwagi kwestii samych Niemiec. W niniejszym opracowaniu zdecydowano się ująć temat wąsko, ograniczając zakres tematyczny, jednocześnie znacząco powiększając próbę badawczą oraz włączając do niej audycje emitowane w 2015 roku. Porównanie tych okresów umożliwiło uchwycenie istoty zmian w narracji Wiadomości. W trwającej wśród metodologów, już od czasów Berelsona (1952), dyskusji nad doborem próby dla potrzeb analizy zawartości (Luke, Caubernay, Cohen, 2011, s. 76-91; Neuendorf, 2002, s. 83-94; Krippendorff, 2004, s. 11-124), jej wielkość pozostaje w nierozerwalnym związku z adekwatnością badań.

W przypadku metodologii zastosowanej w tej pracy, biorąc pod uwagę zakładaną niewielką ekspozycję tematyki niemieckiej w programach informacyjnych, zakreślono szerokie ramy czasowe analizy. W tym miejscu warto podkreślić, że możliwości zastosowanego w badaniach systemu (CAST), ułatwiły podjęcie takiej decyzji. Duża próba pozwala na wyciągnięcie wniosków na wysokim poziomie pewności.

${ }^{1}$ W lipcu 2014 roku pojawił się on jako jeden z mówców na konwencji PiS i już w kolejnym roku powołano go na wiceministra w resorcie Kultury i Dziedzictwa Narodowego w rządzie Beaty Szydło. 


\section{Założenia badawcze}

Autorzy postanowili sformułować następujące hipotezy:

- wątki dotyczące Niemiec mogą być wplatane w inne narracje, by nadać im określony wymiar, a tym samym podsunąć sposób interpretacji (kryzys uchodźczy, pozycja Niemiec w Unii Europejskiej, kapitał zagraniczny w Polsce, wydarzenia w polityce krajowej);

- w roku 2017 wzrośnie poziom instrumentalizacji Wiadomości TVP w odniesieniu do tematyki niemieckiej, co zaowocuje częstszym niż w 2015 r. przedstawianiem Niemiec w negatywnym kontekście.

Badanie pozwoliło również odpowiedzieć na pytania o to, jak często tematyka niemiecka pojawiała się w głównym wydaniu Wiadomości, jak rozkładała się w czasie i co spowodowało wzrost jej widoczności, a także jakie osoby występowały w emitowanych materiałach.

\section{Metodologia}

W badaniu wykorzystano CAST (Content Analysis System for Television) - komputerowy system wspomagający analizę zawartości mediów, który został stworzony na Wydziale Nauk Politycznych i Dziennikarstwa Uniwersytetu im. Adama Mickiewicza w Poznaniu. Umożliwia on jednoczesne odbieranie kilkuset kanałów telewizyjnych i propagowanie ich w sieci komputerowej dzięki technologii streamingu multicastowego. System od 2014 r. rejestruje następujące kanały: TVP 1 i 2, TVN, Polsat, TVN24 oraz TVP Info. Tak obszerny materiał badawczy umożliwia badania ex-post i prowadzenie szerokich studiów porównawczych, umożliwiając niespotykany wcześniej dostęp do programów telewizyjnych, co zostało wykorzystane w niniejszym badaniu. Każdy materiał automatycznie otrzymuje opis generowany na podstawie danych EPG (Electronic Program Guide), w tym: tytuł audycji, krótki opis, nazwa kanału, data nadania, czas trwania etc. Ponadto CAST umożliwia transkrybowanie mowy na tekst, co ułatwia wyszukiwanie określonych audycji.

Dostęp do systemu możliwy jest z poziomu przeglądarki WWW, co pozwala $\mathrm{w}$ elastyczny sposób prowadzić proces kodowania, bowiem użytkownicy mogą pracować na dowolnym komputerze z dostępem do internetu. CAST pozwala stworzyć formularz badania, w którym opisuje się poszczególne jednostki analizy. Ułatwia to proces kodowania - lista analizowanych audycji, klucz kategoryzacyjny, odtwarzacz video, wy- 


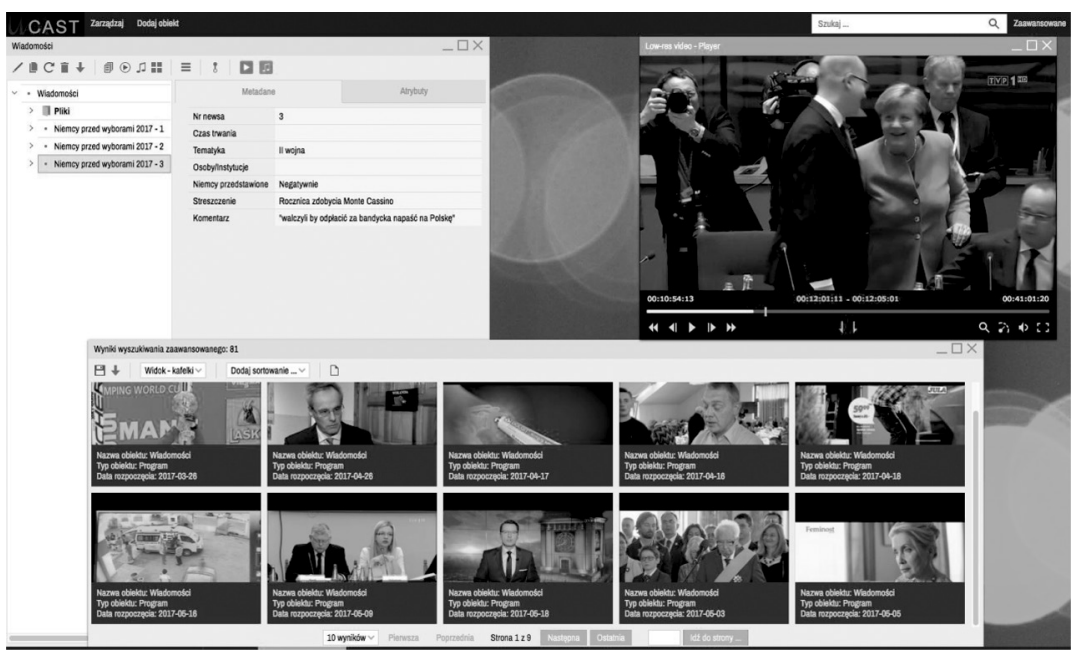

Rys. 1. Widok interfejsu CAST

Źródło: Opracowanie własne.

świetlane są w pojedynczym oknie przeglądarki. Dzięki użyciu CAST badacze mogli sprawnie zakodować badany materiał.

Próba objęła wszystkie główne wydania Wiadomości, wyemitowane w okresie od 1 marca do 31 maja w 2015 r. oraz w tych samych miesiącach w roku 2017. Badanie zostało przeprowadzone w okresie od czerwca do sierpnia 2017 r. Zostało to podyktowane założeniem, że instrumentalizacja treści emitowanych przez Telewizję Polską ma charakter progresywny. Dla porównania wybrano analogiczny okres w roku 2015. Autorzy zdecydowali się wybrać 3 miesiące bezpośrednio poprzedzające moment rozpoczęcia badań, co wynikało ze wspomnianej już prośby badaczy z Uniwersytetu w Poczdamie oraz terminu prezentacji wyników dociekań podczas konferencji naukowej.

Analizie poddano łącznie 184 wydania, relewantne newsy zawierało $78 \mathrm{z}$ nich. Z próby wykluczono informacje o tematyce sportowej oraz te, w których Niemcy zostały wspomniane na marginesie, w sposób incydentalny (na przykład, gdy w materiale wspomniano o obywatelu Niemiec, będącym jedną z ofiar zamachu). Jednostką analizy był jeden news; łącznie badaniu poddano 145 zawierających odniesienia do Niemiec. Jak wspomniano na wstępie, stosunkowo duży rozmiar próby wynikał z założenia, poczynionego na etapie badania pilotażowego, które zostało do pewnego stopnia potwierdzone w wynikach badań właści- 
wych, że tematyka niemiecka będzie prezentowana na antenie raczej rzadko.

W przygotowanym kluczu znalazły się następujące kategorie:

- czas trwania newsa;

- osoba wypowiadająca się - liczony był wyłącznie czas wypowiedzi (,setki”), nie brano pod uwagę incydentalnych wystąpień danej osoby czy wspomnienia o niej w materiale. Kodowano wszystkich obywateli Niemiec;

- tematyka - kategoria koniunktywna, tworzona ad hoc, w trakcie badania.

Oprócz powyższych, których kryteria nie budzą wątpliwości ujęto też jedną wymagającą dokładniejszej operacjonalizacji - „sposób przedstawienia Niemiec". W trakcie procesu kodowania przewidziano cztery odpowiedzi: pozytywnie, negatywnie, neutralnie oraz ambiwalentnie. Rozumienie tych kategorii nie odbiega od analiz realizowanych przez innych badaczy (Idzik, Klepka, 2019, s. 24; Niven, 2003, s. 316-319). W pierwszym przypadku materiał prezentował Niemcy w sposób przychylny, aprobatywny, zarówno biorąc pod uwagę treść informacji, jak i ewentualny komentarz. A contrario, do przedstawiających Niemcy w sposób negatywny jednostek analizy, zaliczono te, w których były one przedstawiane w sposób krytyczny i stawiający je w niekorzystnym świetle. Za neutralne uznano materiały, w których nie pojawiały się sądy wartościujące, o charakterze wyłącznie informatywnym, ograniczającym się wyłącznie do faktów. Do ambiwalentnych autorzy zaliczyli nieliczne materiały, w których występowały zarówno przychylne, jak i nieprzychylne sądy, opinie i ewentualne komentarze redakcyjne, co utrudniało jednoznaczne stwierdzenie, jaki ma wydźwięk.

Autorzy kodowali materiał wspólnie, eliminując konieczność przeprowadzenia weryfikacji zgodności koderów. Takie podejście pozwoliło także na sprawne stworzenie spójnej listy obszarów tematycznych badanych newsów.

\section{Wyniki badań}

Jak widać na wykresach 1 i 2, tematyka niemiecka w badanych okresach poruszana była raczej rzadko, pojawiając się średnio w mniej niż $10 \%$ newsów. Należy jednak zwrócić uwagę na wyraźny wzrost jej obecności w roku 2017 - 8 punktów procentowych jest trudne do przeoczenia. 
Wykres 1. Odsetek newsów dotyczących Niemiec w badanym okresie 2015 roku

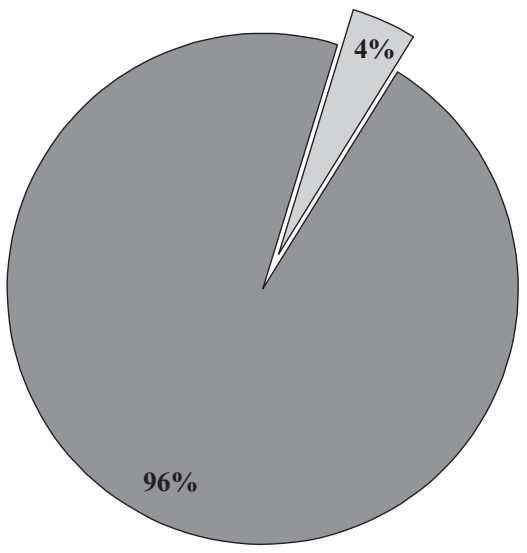

Newsy dotyczące Niemiec

Ogół newsów

Źródło: Opracowanie własne.

Wykres 2. Odsetek newsów dotyczących Niemiec w badanym okresie 2017 roku

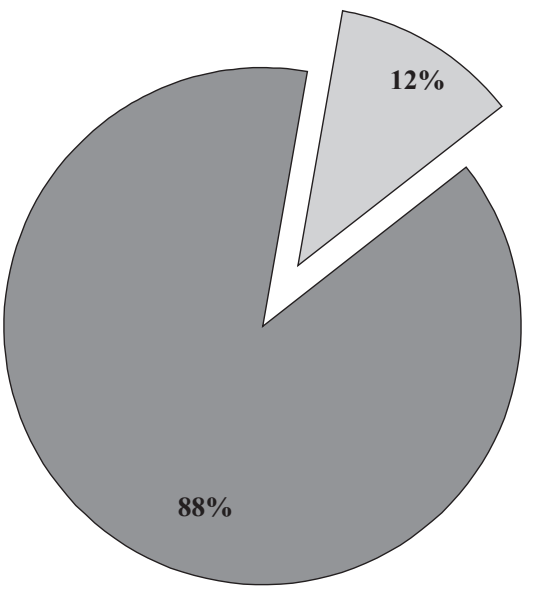

Newsy dotyczące Niemiec

Ogół newsów

Źródlo: Opracowanie własne.

Na wykresie 3 można zauważyć kilka miejsc, w których nastąpił wzrost ekspozycji tematyki niemieckiej. W 2015 roku (linia przerywana) były to: - koniec marca - katastrofa samolotu linii GermanWings w okolicach Prads-Haute-Bléone we Francji; 


\section{Wykres 3. Rozklad w czasie}

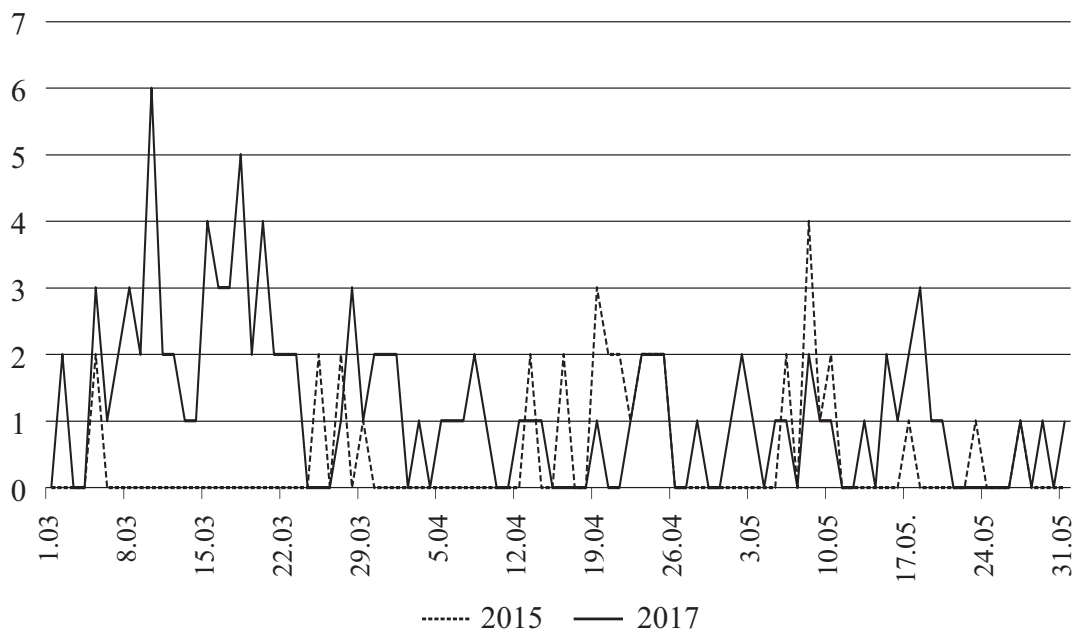

Źródło: Opracowanie własne.

- kwiecień - wypowiedź Jamesa Comey’a, dyrektora FBI, w której obok Niemców, obarczył on Polaków odpowiedzialnością za Holocaust;

- początek maja - obchody rocznicy zakończenia II wojny światowej.

W 2017 odnotować należy również trzy kluczowe momenty wzrostu widoczności Niemiec i Niemców na antenie Wiadomości:

- początek marca - ponowny wybór Donalda Tuska na przewodniczącego Rady Europejskiej przy sprzeciwie strony polskiej;

- koniec marca - obecność Polski na szczycie G-20 w Hamburgu na zaproszenie Niemiec oraz kwestia listu Marka Dekana, prezesa zarządu wydawnictwa Ringier Axel Springer Media do polskich pracowników koncernu, w którym pisał on, że wolność, demokracja, rządy prawa, demokracja oraz Europa są wartościami, które reprezentuje grupa Onet-RAS Polska;

- połowa maja - obrady Parlamentu Europejskiego, których tematem był kryzys uchodźczy.

Wiele kategorii przedstawionych na wykresie 4 jest związanych z bieżącymi wydarzeniami i jako takie nie pojawiają się w drugim z porównywanych okresów. Dotyczy to kategorii: Comey, Germanwings, Brexit, polski kryzys konstytucyjny, repolonizacja mediów, Wybory do Bundestagu. Na uwagę zasługuje zmiana poziomu ekspozycji dwóch katego- 
Wykres 4. Tematyka

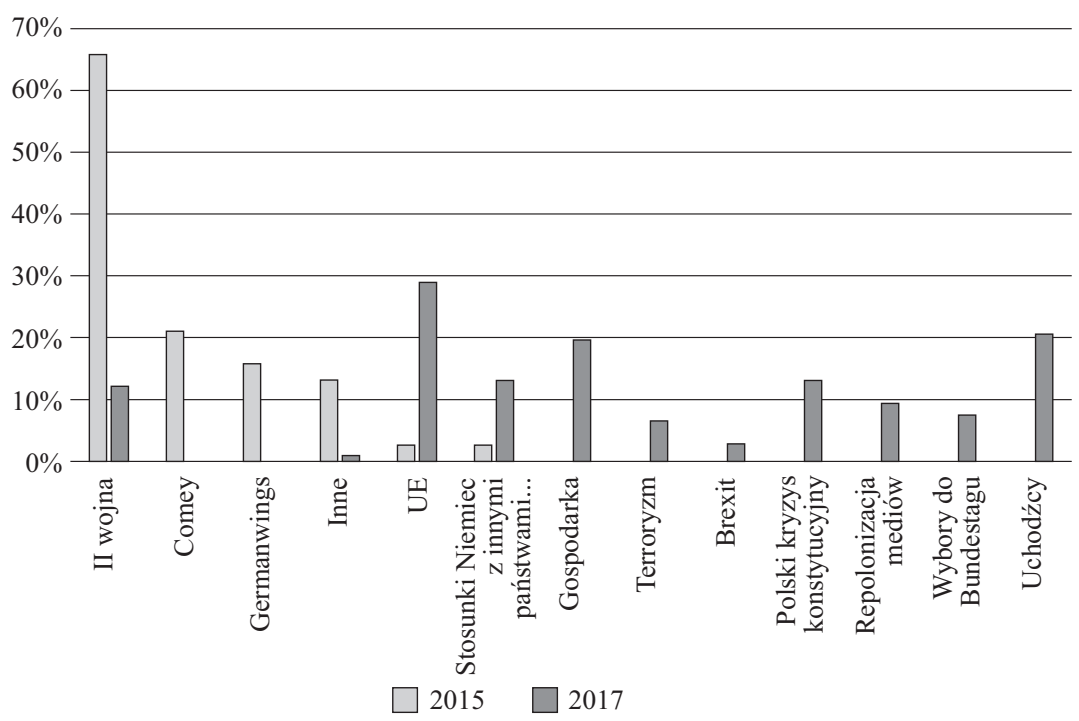

Źródło: opracowanie własne.

rii: II wojna światowa oraz Unia Europejska (zob. wykres 4). Tematyka II wojny światowej pojawiała się w 66\% newsów w roku 2015. Były to najczęściej materiały emitowane $\mathrm{w}$ związku $\mathrm{z}$ rocznicami wydarzeń z tamtego okresu. Jako takie, wpisywały się w klasyczną, informacyjną rolę mediów. W 2017 r., choć charakter materiałów pozostał zbliżony, stanowiły one już tylko $12 \%$ ogółu materiałów dotyczących Niemiec. Olbrzymi wzrost zaobserwować można w kategorii Unia Europejska, w którym to kontekście Niemcy niemal nie pojawiały się w pierwszym z badanych okresów. W drugim, to już niemal 30\%. Z czego $38 \%$ to newsy przedstawiające Niemcy w sposób negatywny. Trudno znaleźć inne uzasadnienie takiego stanu rzeczy niż zbieżność narracji „Wiadomości” z retoryką polskiego rządu względem Niemiec - odgrywających hegemoniczną rolę w tej organizacji.

Zasadniczą zmianę w ekspozycji Niemiec w analizowanych okresach można dostrzec, gdy weźmie się pod uwagę sposób prezentowania tej tematyki na antenie Wiadomości TVP. O ile odsetek materiałów o pozytywnym i ambiwalentnym wydźwięku jest zbliżony (11\% w 2015 roku i 13\% w roku 2017 oraz odpowiednio 8\% i 7\%), to różnicę widać w odniesieniu do materiałów o wydźwięku neutralnym i negatywnym. W pierwszym 


\section{Wykres 5. Sposób przedstawiania Niemiec}

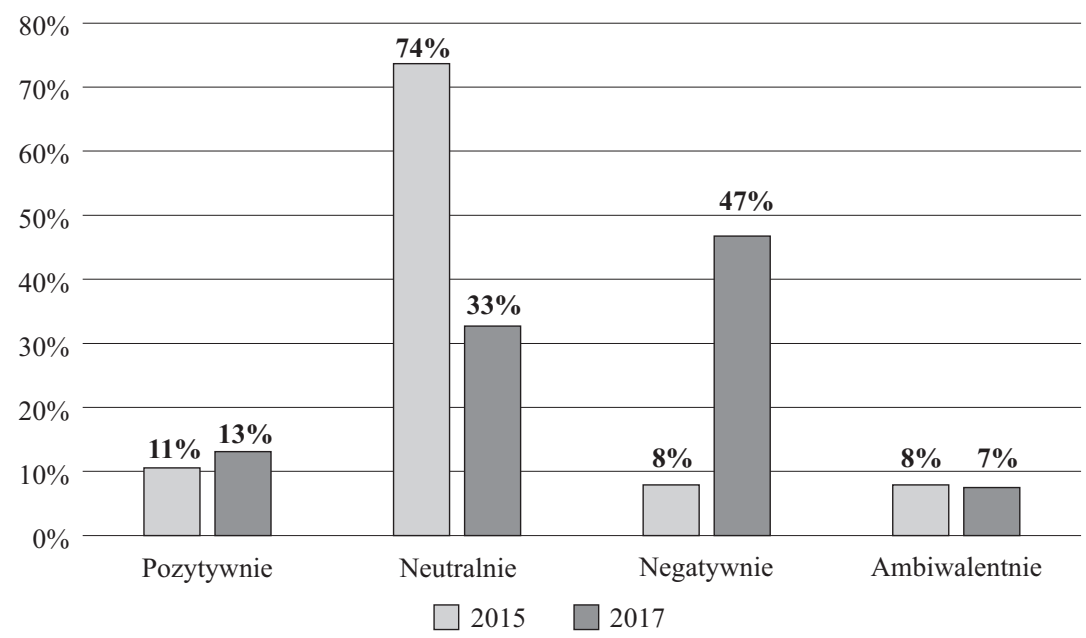

Źródło: Opracowanie własne.

przypadku odsetek ten wyniósł w roku 2015 - 74\%, w 2017 - 33\%, z kolei negatywny wydźwięk można dostrzec w 8\% materiałów dotyczących Niemiec w 2015 roku i 47\% w roku 2017.

Wykres 6. Odsetek newsów o negatywnym wydźwięku w 2017 roku

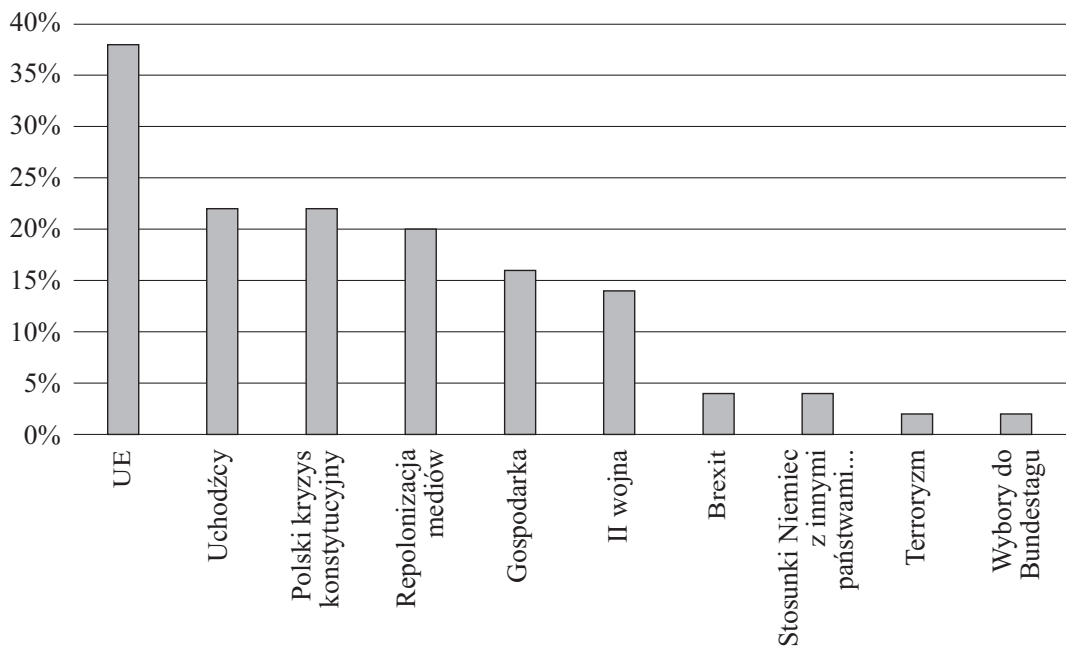

Źródło: Opracowanie własne. 
Wykres obrazujący rozkład tematyki, w której Niemcy prezentowane były w negatywnym kontekście, ukazuje zjawisko wplatania tych wątków w narracje nawiązujące do Polski. Dowodzi to instrumentalnego traktowania figury Niemiec, która stanowi negatywny punkt odniesienia dla omawianych zagadnień. Tak stało się chociażby w przypadku kryzysu uchodźczego, o spowodowanie którego obwiniano Niemcy i przed którym obywateli zamierzał uchronić rząd. Również list prezesa wydawnictwa Ringier Axel Springer, posłużył do budowania narracji wspierającej konieczność repolonizacji (nacjonalizacji?) środków przekazu w Polsce. Jak wynika $\mathrm{z}$ wypowiedzi prezentowanych na antenie, będąc w obcych rękach, służą one interesom innych państw, szczególnie Niemiec. Te zagadnienia przeplatały się z tematyką kryzysu konstytucyjnego w Polsce, w przypadku którego wskazywano na Niemcy, jako kraj, którego rząd ingeruje w sprawy wschodniego sąsiada, bowiem jest zaniepokojony polską samodzielnością (owym wstawaniem z kolan, do którego odwoływali się politycy rządzącego obozu) i odzyskiwaną podmiotowością (co odróżniało go od uległych rządów Donalda Tuska i Ewy Kopacz). Najliczniejszą grupę informacji, w których negatywnie prezentowano Niemcy, stanowiły materiały dotyczące Unii Europejskiej. Wynika to między innymi z reelekcji Donalda Tuska na stanowisko przewodniczącego Rady Europejskiej, czemu sprzeciwiał się polski rząd, który wystawił własnego kandydata, Jacka Saryusza-Wolskiego. Przeforsowanie wyboru Donalda Tuska na to stanowisko ukazywano w Wiadomościach w kontekście dominującej pozycji Niemiec w Unii Europejskiej, która w zasadzie służyć ma realizacji interesów tego państwa. Na ich poparcie mogą liczyć ci politycy, którzy taki stan rzeczy akceptują, wyrzekając się autonomii. Taka optyka pozwalała również krytykować opozycję, sugerując zdradę interesów Polski i działanie wbrew polskiej racji stanu, na rzecz państw trzecich, przede wszystkim Niemiec.

Wykres 7 ukazuje osoby, które najczęściej pojawiały się w materiałach dotyczących Niemiec. Łatwo zauważyć, że byli to głównie członkowie rządu federalnego: kanclerz, Angela Merkel oraz minister spraw zagranicznych, Frank Walter-Steinmeier.

Tendencja ta jest jeszcze bardziej widoczna w badanym okresie roku 2017, w którym Angela Merkel pojawiała się częściej niż pozostałe osoby łącznie. Zaskakiwać może nikła obecność przewodniczącego Socjaldemokratycznej Partii Niemiec, Martina Schulza, który był wskazywany jako główny kontrkandydat urzędującej kanclerz w wyborach we wrześniu 2017 roku. Na uwagę zasługuje fakt, że w porównaniu z ro- 
Wykres 7. Osoby występujące w badanych materiałach w 2015 roku 4

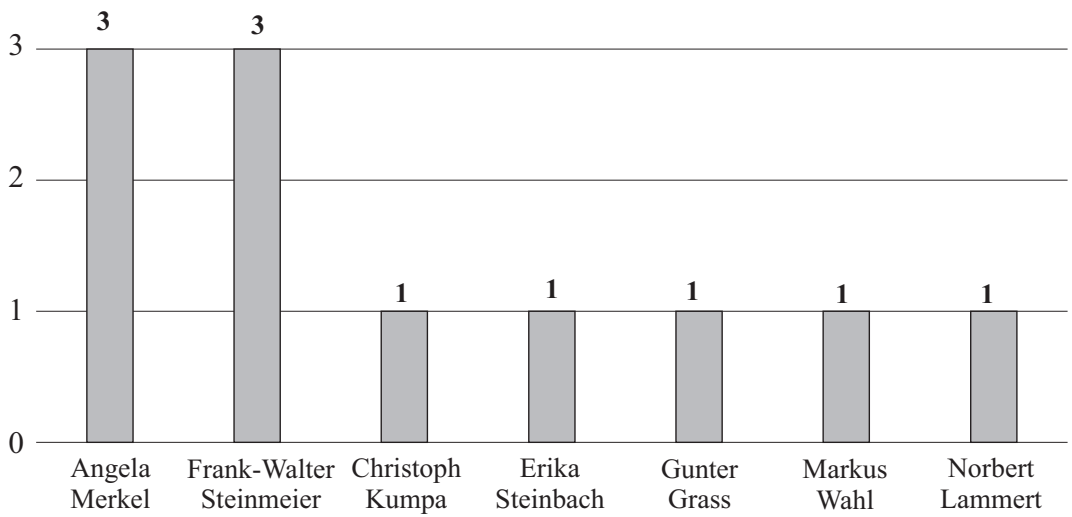

Źródło: Opracowanie własne.

Wykres 8. Osoby występujące w badanych materiałach w 2017 roku

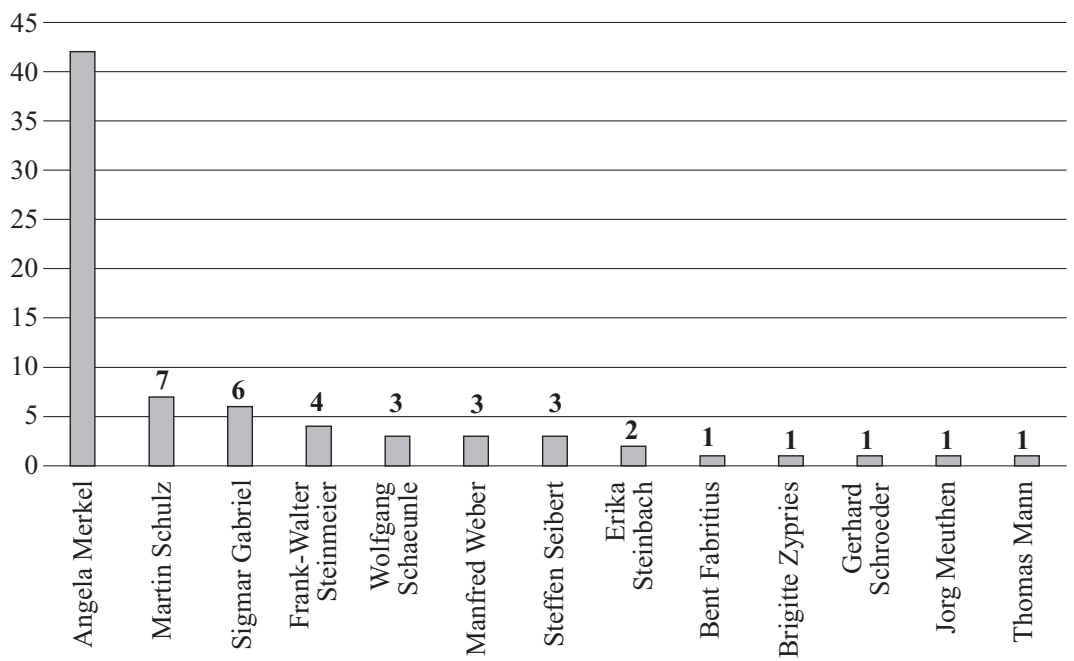

Źródło: Opracowanie własne.

kiem 2015, w materiałach nowszych zdecydowanie wzrosła ekspozycja niemieckich polityków. Na 107 newsów dotyczących Niemiec w 2017 roku, Angela Merkel pojawiła się w 42 z nich. Procentowo to więcej niż 
wszyscy Niemcy, którzy pojawili się w Wiadomościach w analizowanym okresie 2015 roku. Biorąc pod uwagę nieprzychylny wydźwięk większości materiałów, można zaryzykować stwierdzenie, iż w optyce redakcji stała się ona uosobieniem negatywnych cech przypisywanych Niemcom.

\section{Wnioski}

Wydarzenia w Niemczech nie były szeroko komentowane w głównym serwisie informacyjnym telewizji publicznej, co jest zaskakujące chociażby w kontekście wyborów do Bundestagu. Być może redakcja uznała jednak, iż ich odległy termin (24 września 2017 roku) nie uzasadniał relacjonowania kampanii wyborczej w analizowanym okresie. Zauważalna jest dysproporcja w liczbie informacji w latach 2015 i 2017 oraz ich wydźwięk. O ile bowiem w 2015 roku przeważały materiały neutralne w stosunku do Niemiec, to w roku 2017 przeważająca część materiałów prezentowała niemal wyłącznie jeden punkt widzenia. Taka jednostronność przekazu prowadzi do deformacji obrazu rzeczywistości, dzięki czemu odbiorcy interpretują i definiują ją zgodnie z intencjami nadawców. Nietrudno dostrzec w linii redakcyjnej zbieżność z wypowiedziami polityków strony rządzącej; widać ją chociażby w przypadku odniesień do krytyki pod adresem Polski, która płynie z zagranicy - zostaje ona uznana za wyrażaną z pozycji ideologicznie wrogich. W optyce Wiadomości TVP, na przykład krytyka realizowanych przez rząd PiS zmian w systemie sądownictwa jest zrozumiała, bowiem płynie z Niemiec, kraju Polsce niechętnego. Można wręcz zauważyć, że owa krytyka pozwala tę reformę uwiarygodnić, czyni ją tym bardziej słuszną (por. Przyłęcki, 2012, s. 119, 214-215). W przekazie Wiadomości, dopiero po przejęciu władzy przez Prawo i Sprawiedliwość, Polska zaczęła prowadzić samodzielną politykę zagraniczną, zyskała podmiotowość, której nie miała, będąc zwasalizowanym sojusznikiem Angeli Merkel za rządów poprzedniej koalicji.

Zauważalną tendencją w konstruowaniu medialnego obrazu Niemiec jest wielokrotnie przywoływana narracja o hegemonicznej roli odgrywanej przez to państwo w strukturach Unii Europejskiej, czy szerzej na kontynencie europejskim. Wybrzmiewa to wyraźnie w komentarzach dziennikarzy czy ekspertów:

- „Niemieccy dziennikarze są przekonani, że Berlin ma nad nią [UE] niemal całkowitą kontrolę" (Wiadomości TVP z 10 marca 2017 roku); 
- „Może bardziej by pasowało Europejski Bank Ekspansji Niemiec w Europie albo Bank Neokolonialny" - o Europejskim Banku Odbudowy i Rozwoju, który przyznał pożyczkę niemieckiej sieci handlowej Kaufland (Wiadomości TVP z 30 marca 2017 roku);

- „Bulwersujące praktyki koncernu Ringier Axel Springer, który forsuje przekaz niemieckiego rządu" (Wiadomości TVP z 16 marca 2017 roku);

- „Axel-Springer próbuje zmienić tradycyjny system wartości” (Wiadomości z 28 marca 2017 roku);

- „Niemcy bronią wizerunku Hitlera” (Wiadomości TVP z 5 marca 2017 roku);

- „Niemcy mają problem z chrześcijańskimi korzeniami Europy” (Wiadomości TVP z 20 maja 2017 roku).

Tę antyniemiecką retorykę wykorzystywano w 2017 roku również do oceny bieżących wydarzeń w kraju. Ukazanie niemieckiego poparcia dla kogoś lub czegoś prezentowano jako element pozwalający deprecjonować czy wręcz zohydzać określone osoby, instytucje czy ugrupowania. Pojawiła się wręcz sugestia zdrady, jak w przypadku Donalda Tuska, ponownie - zbieżna z narracją PiS (Orłowski, 2017). W materiałach podkreślano również, że dopiero nowy rząd w Polsce sprawił, że Niemcy zaczęli liczyć się ze swoim wschodnim sąsiadem. Tego typu materiały tworzą system ideologicznych odniesień, który proponuje się odbiorcom, co pozwala tworzyć poczucie wspólnej tożsamości wobec osoby lub grupy osób prezentowanych jako swego rodzaju wróg. Emocjonalna argumentacja, odwołująca się do generalizacji, upraszcza obraz rzeczywistości. Ponownie warto sięgnąc do cytatów:

- „Wałęsa uznał prymat Niemiec nawet nad Polską” (Wiadomości TVP z 10 maja 2017 roku);

- „Na kolejnych unijnych szczytach klimatycznych premierzy z PO zgadzali się na niemieckie propozycje znaczącej redukcji dwutlenku węgla" (Wiadomości TVP z 7 marca 2017 roku);

- „Relacje pol.-niem. ostatnio zmieniły się. Z kraju, który posłusznie zatwierdzał polityczne plany Berlina, staliśmy się ważnym partnerem, który jednak potrafi twardo walczyć o narodowe interesy" (Wiadomości TVP z 8 marca 2017 roku);

- „Bardzo często się dzisiaj krytykuje z różnych stron TVP. Gdyby ona nie była troszeczkę mocniej zaangażowana $\mathrm{w}$ obronę wartości polskich, polskiej racji stanu, to właściwie tamte niemieckie koncerny by rządziły" (Wiadomości TVP z 18 marca 2017 roku); 
- „Zaniepokojona losem muzeum jest także państwowa niemiecka telewizja. Jest to o tyle dziwne, że jak wiele wskazuje na to, tak naprawdę te media niemieckie są inspirowane z Polski. Jest to element akcji lobbingowej mającej na celu zachowanie status quo w gdańskim muzeum. Jednym z celów tejże ekspozycji muzealnej było wejście $w$ taki pożądany przez stronę niemiecką dialog dotyczący rozliczenia się z latami II wojny światowej. Dlaczego spór o muzeum rozpala tak ostre polityczne emocje także za Odrą? Widać, że nie chodzi tylko o muzeum. Widać wyraźnie, że tak naprawdę chodzi o kształt polskiej polityki historycznej, ale także i o kształt niemieckiej polityki historycznej. A takie placówki jak polskie muzea muszą kierować się wyłącznie polską polityką historyczną" (Wiadomości TVP z 6 kwietnia 2017 roku).

\section{Bibliografia}

Berelson B. (1952), Content analysis in communication research, New York.

Doktorowicz K. (2010), Polski system mediów publicznych. Jak to się stało?, w: Media publiczne. System medialny w Polsce - pytania i dezyderaty, pod red. P. Bielawskiego, A. Ostrowskiego, Wrocław.

Idzik J., Klepka R. (2019), O analizie zawartości, czyli jak badać medialne obrazy świata?, w: Medialne obrazy świata, t. 2: Polityka i bezpieczeństwo $w$ relacjach medialnych, pod red. R. Klepki, J. Idzika, Kraków.

Luke D., Caburnay C., Cohen E. (2011), How Much Is Enough? New Recommendations for Using Constructed Week Sampling in Newspaper Content Analysis of Health Stories, "Communication Methods and Measures", 5, s. 76-91.

Krippendorff K. (2004), Content Analysis. An Introduction to Its Methodology, Sage Publications.

Mrozowski M., Popadiak-Kuligowska T. (2016), Ekspertyza programów informacyjnych głównych wydań TVP1 Wiadomości, TVN Fakty, Polsat Wydarzenia z okresu 4.02.2016 r. do 11.02.2016 r. Raport końcowy, Warszawa, http:// www.krrit.gov.p1/Data/Files/_public/Portals/0/komunikaty/12.04.2016/krrit_ eksperyza.pdf, 23.01.2018.

Neuendorf K. (2002), The Content Analysis Guidebook, Sage Publications.

Niven D. (2003), Objective Evidence on Media Bias: Newspaper Coverage of Congressional Party Switchers, "Journalism \& Mass Communication Quarterly", $80(2)$, s. 311-326.

Orłowski M. (2017), PiS w spocie wideo manipuluje i oskarża Tuska o zdradę. Sprawdziliśmy teze po tezie, „Gazeta Wyborcza”, https://wyborcza. pl/7,75398,21471645, pis-w-spocie-wideo-manipuluje-i-oskarza-tuska-ozdrade-sprawdzilismy.html, 24.01.2018. 
Piechocki M., Wyszyński J. (2018), The image of Russia in the Wiadomości news service of Polish National Television in 2017, „PolitBook”, nr 4.

Przyłęcki P. (2012), Populizm w polskiej polityce. Analiza dyskursu polityki, Wydawnictwo Sejmowe, Warszawa.

Riffe D., Stephen L., Frederick F. (2014), Analyzing media messages: Using quantitative content analysis in research, Third edition, Taylor and Francis.

ROB (2005), Gra z dziadkiem przegrana, „Express Bydgoski” z 11 października 2005.

Ustawa z dnia 22 czerwca 2016 r. o Radzie Mediów Narodowych, Dz. U. 2016, poz. 929.

Wyrok Sądu Najwyższego z dnia 13 grudnia 2005 r.. Sygnatura: IV CK 304/05, http:// www.sn.pl/orzecznictwo/SitePages/Baza_orzeczen.aspx?Sygnatura=IV\%20 CK\%20304/05, 26.01.2018.

\section{The Good Change? The image of Germany in the Wiadomości news service of Polish National Television in 2015 and 2017}

\section{Summary}

This article draws upon content analysis of the leading evening news program on Polish public television - Wiadomości. The authors examine how Germany was presented in this news service. The research sample includes every news item concerning Germany that was broadcast from March 1 to May 31 in 2015, and in the same period in 2017. The study shows that Germany is often used instrumentally and in a negative context.

Key words: TVP, content analysis, Germany, television 
